\title{
EFFICIENCY OF THE MAIN FISHING GEARS USED IN PRAWN FISHERY IN THE JAFFNA LAGOON
}

\author{
K. CHITRAVADIVELU \\ Department of Zoology, University of Jaffna, Jaffna, Sri Lanka.
}

\author{
(Date of receipt \\ 18 October 1988) \\ (Date of acceptance \\ O3 January 1990)
}

\begin{abstract}
The main gears used in prawn fishery in the Jaffna Lagoon are 'sirahu valai', drag net, hoop net and 'kandi'. 'Sirahu valai' collects the largest prawns and is less efficient with an average CPUE of $3.70 \mathrm{Kg}$. gear $^{-1} \mathrm{day}^{-1}$ and more expensive than the other gears. 'Kandi', the cheapest of the gears is operated only at a few locations in the lagoon and is being abandoned due to its poor efficency (CPUE of $1.88 \mathrm{Kg}$. gear ${ }^{-1} \mathrm{day}^{-1}$ ). The drag net with an average CPUE of $6.12 \mathrm{Kg}$. gear $^{-1} \mathrm{day}^{-1}$ is the most efficient gear. However, this gear collects the smallest prawns especially Metapenaeus monoceros and Ponaeus semisulcatus, during the months of May and: October. January was the most productive month as far as the fishery in Jaffna lagoon was concerned. The year 1987 with an annual average CPUE of $4.04 \mathrm{Kg}$. gear $^{-1}$ day $^{-1}$ was more productive than 1986 with an average CPUE of $3.77 \mathrm{Kg}$. gear $^{-1} \mathrm{day}^{-1}$. Considering the average total length of prawns caught in the different gears and their CPUE during 1986 and 1987, a total ban or at least a restriction on the use of drag net during the months of May and October in the Jaffna lagoon is recommended.
\end{abstract}

\section{Introduction}

Prawns are considered a luxury food commodity in international trade and are one of the world's most profitable resources. They supply the increasing population with proteins and provide significant earnings of foreign exchange. The prawn industry has thus assumed major importance in recent years in Sri Lanka and abroad. The most productive fishing grounds and the majority of the species of high commercial interest are found in the tropics. ${ }^{10}$ Most of the current production of prawns in Sri Lanka comes from lagoons. ${ }^{1}$

The high demand in the world market of the richer countries gives a strong incentive to the development of prawn fisheries. Sri Lanka seems alive to this situation. With the operation of a number of prawn processing factories in the North of Sri Lanka, there is a big demand and a ready market for prawns in Jaffna. This results in competition among fishermen and in the absence of any regulatory measures, inevitably leads to overexploitation and finally to an overall reduction of total value of catches.

The Jaffna lagoon is the largest water body situated in the Northern 'part of Sri Lanka and lies between approximately $79^{\circ} 52^{\prime} \mathrm{E}$ to $80^{\circ} 38^{\prime} \mathrm{E}$ long. and $9^{\circ} 26^{\prime} \mathrm{N}$ to $90^{\circ} 46^{\prime} \mathrm{N}$ lat. This has an area of approximately $421 \mathrm{Km}^{2}$ (Figure 1). The lagoon is connected to the sea at Punnalai, between Karaitivu and Kayts and between Kalmunai and Mandaitivu. Tidal currents entering and flowing out through these channels effect mixing of water. Five distinct bays - Punnalai Bay, Velichavedu Bay, Kalundai Bay, Ariyalai Baỳ and Kachchai Bay are marked out in the lagoon ${ }^{13}$ (Figure 1). 


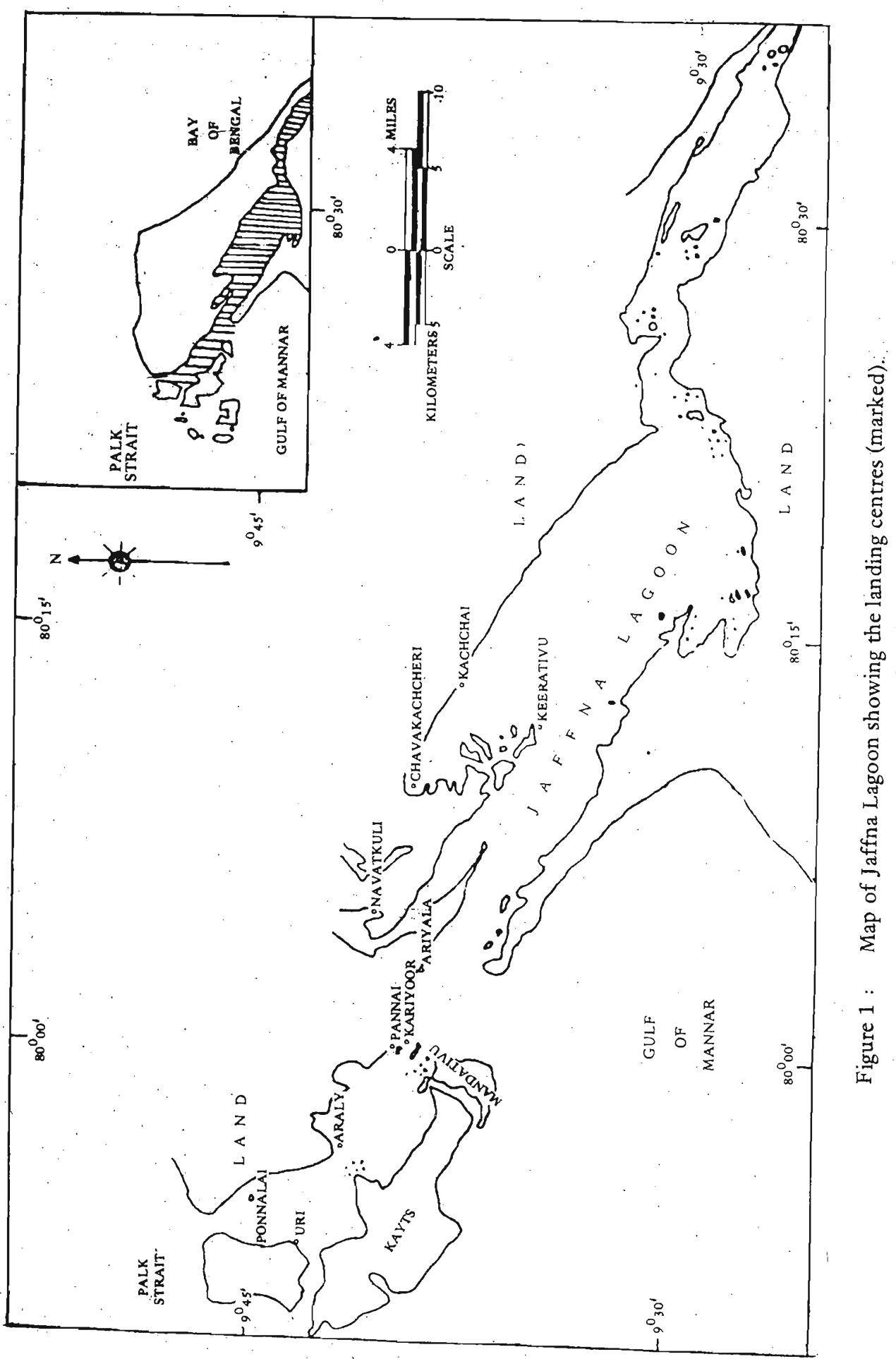


The lagoon is shallow, depths do not exceed four meters and is navigable through the few channels which are generally $1.0 \mathrm{~m}$ to $1.5 \mathrm{~m}$ in depth. The shore line of the lagoon is sandy. Punnalai Bay has a distinct loose bottom characterised by coarse sticky mud, while the areas other than the channels in Kalundai Bay and Ariyalai Bay have coarse non-sticky mud bottom which is relatively more firm. The bottom of the channel all along the lagoon has slate coloured fine soft sticky mud. ${ }^{13}$

Satchithananthan and Thevathasan ${ }^{14}$ have reported on the structure and operation of 'sirahu valai' in the Jaffna lagoon. Preliminary investigations carried out by Chitravadivelu and Arudpragasm ${ }^{3}$ have indicated that there are five species of penaeid prawns in the Jaffna lagoon and that they are collected mainly by four gears. There is no other information on the nature of available prawn resources, their biology, gears used and their performance in the Jaffna lagoon. The present investigation was undertaken. from January 1986 to December 1987 to evaluate the performance of the different gears used in prawn fishery and to assess the prawn fishery. This will aid in the adoption of suitable management measures and improve yields in the Jaffna lagoon.

\section{Materials and Methods}

Random samples of prawns were taken from the total catch of similar gears of identical dimensions, operated for a day, from ten landing centres extending from Ponnalai to Keerativu, twice a month (Figure 1). Gears were either supplied or partly financed and cost of maintenance met by the investigator to maintain uniformity. The dimensions and mesh sizes of the gears are described by Chitravadivelu and Arudpragasm. ${ }^{3}$

The table below gives the dimension and mesh sizes of the gears used in this investigation.

Table 1

\begin{tabular}{|c|c|c|c|c|c|}
\hline \multirow[t]{2}{*}{ GEAR } & \multirow[t]{2}{*}{ Components } & \multicolumn{3}{|c|}{ Dimensions in $\mathrm{m}$} & \multirow{2}{*}{$\begin{array}{c}\text { Mesh size } \\
\text { in } \mathrm{mm}\end{array}$} \\
\hline & & Length & $\begin{array}{l}\text { breadth/ } \\
\text { height }\end{array}$ & diameter & \\
\hline $\begin{array}{c}\text { Sirahu- } \\
\text { valai }\end{array}$ & $\begin{array}{l}\text { Leader } \\
\text { Wing } \\
\text { Chamber }\end{array}$ & $\begin{array}{r}100 \\
15\end{array}$ & $\begin{array}{l}2.0 \\
2.0 \\
2.0\end{array}$ & $\begin{array}{l}--- \\
--- \\
5.0\end{array}$ & $\begin{array}{r}11.0 \\
11.0 \\
8.0\end{array}$ \\
\hline Drag net & $\begin{array}{l}\text { Bag } \\
\text { Pouch }\end{array}$ & $\begin{array}{l}9.5 \\
9.5\end{array}$ & $\begin{array}{l}2.5 \\
1.3\end{array}$ & $\begin{array}{l}--- \\
---\end{array}$ & $\begin{array}{r}9.0 \\
16.0\end{array}$ \\
\hline Hoop net & $\begin{array}{l}\text { Cage } \\
\text { Large ring } \\
\text { Large barrier } \\
\text { Small barrier }\end{array}$ & $\begin{array}{c}4.0 \\
--- \\
13.5 \\
3.2\end{array}$ & $\begin{array}{l}\cdots- \\
\cdots \\
1.3\end{array}$ & 0.5 & \begin{tabular}{l}
10.0 \\
\hdashline-0.0 \\
10.0
\end{tabular} \\
\hline Kandi & $\begin{array}{l}\text { Outer cone } \\
\text { Inner cone }\end{array}$ & $\begin{array}{l}1.2 \\
0.7\end{array}$ & -- & 0.45 & $\begin{array}{l}3.0 \\
3.0\end{array}$ \\
\hline
\end{tabular}


The weight of the total catch of prawns from each gear per operation day, date of collection, name of the landing centre and the type of gear used were recorded for each sample collected. Samples were brought to the laboratory for detailed analysis.

The temperature of air and surface water, $\mathrm{pH}$ and salinity were also recorded at each station. Rainfall data was obtained from the Meterological Office at Kankesanthurai. Initially each sample was separated into different species and the number of specimens in each species was counted.

The carapace length and total length of each specimen in the sample were measured to the nearest millimeter; the former using a Vernier caliper and the latter using a measuring board. The carapace length is the distance from the orbital notch to the posterior dorsal margin of the carapace and the total length is the distance from the tip of the rostrum to the tip of the telson. Weight of each specimen was determined by means of a Ohaus Triple Beam balance (Model 700) and recorded to the nearest milligram.

The structure, cost of construction and mode of operation of each gear were studied in detail. The average catch per unit of effort (CPUE) for each gear and the average total length of each species of prawn caught in the different types of gears were calculated. CPUE was calculated taking an operation day as the unit of effort and expressed in weight, $\mathrm{Kg}$. gear ${ }^{-1}$ day $^{-1}$.

The seasonal trends of catches in terms of an average seasonal index ${ }^{11}$ of the prawn catches were determined. The index is equal to 100 when the observed catch is the same as the expected monthly meari. The monthly mean is obtained by dividing the sum of the monthly average CPUE for each gear by 12 .

Four hundred and seventy samples collected at the different landing centres of the Jaffna lagoon, comprising 42,792 penaeid prawns were analysed during the period of investigation.

Prawns are caught in the Jaffna lagoon mainly by (i) sirahu valai or stake net (ii) drag net (raal valai) (iii) hoop net (raal koodu) and (iv) kandi (trap of tidal weirs or cone cage or aproned cone cage). The structure and mode of operation of these gears are described in detail by Pearson, ${ }^{9}$ Sachithananthan and Thevathasan, ${ }^{14}$ Kurian and Sebastian, ${ }^{7}$ Chitravadivelu and Arudpragasm ${ }^{3}$ and Chitravadivelu. ${ }^{4}$ The drag net is an active gear while the other three gears are passive stationary gears. ${ }^{8}$ (Table 2).

The present approximate cost of each unit of gear is given below. 
Table 2.

\begin{tabular}{lc}
\hline GEAR & Cost in Rs. \\
\hline Sirahu valai & $4,000.00$ \\
Drag net & $1,000.00$ \\
Hoop net & $2,000.00$ \\
Kandi & 500.00 \\
\hline
\end{tabular}

All the four gears are used approximately for twenty days in a month.

Apart from the four main gears mentioned above, two other methods used occasionally in the exploitation of prawns in the Jaffna lagoon are (i) use of cast nets of 5/8" mesh size and (ii) hand picking. Cast nets are used for prawns usually from October to April. Hand picking of prawns is done by ladies, at knee deep waters, especially at Ponnalai Bay during December to April.

\section{Results}

The monthly variations of air and surface water temperatures in the Jaffna lagoon during 1986 and 1987 are shown in Figure 2a. The air temperature was the lowest during November $\left(22.5^{\circ} \mathrm{C}\right)$ in 1986 . In 1987 the lowest air temperature was recorded in September $\left(25.2^{\circ} \mathrm{C}\right)$. The lowest temperature of surface water was recorded during September $\left(23.2^{\circ} \mathrm{C}\right)$, in 1986 . In 1987 the lowest surface water temperature was during January and September $\left(24.3^{\circ} \mathrm{C}\right.$ ) (Figure 2a).

In January 1986, the Jaffna lagoon had the lowest salinity of 16.8 ppt. The highest salinities recorded were during August and September and were in the range of 34.5 ppt. and 34.75 ppt. In 1987, the lowest salinity of 20.25 ppt. was recorded in January and the highest of 36.3 ppt. in August (Figure 2b). 
RAINFALL

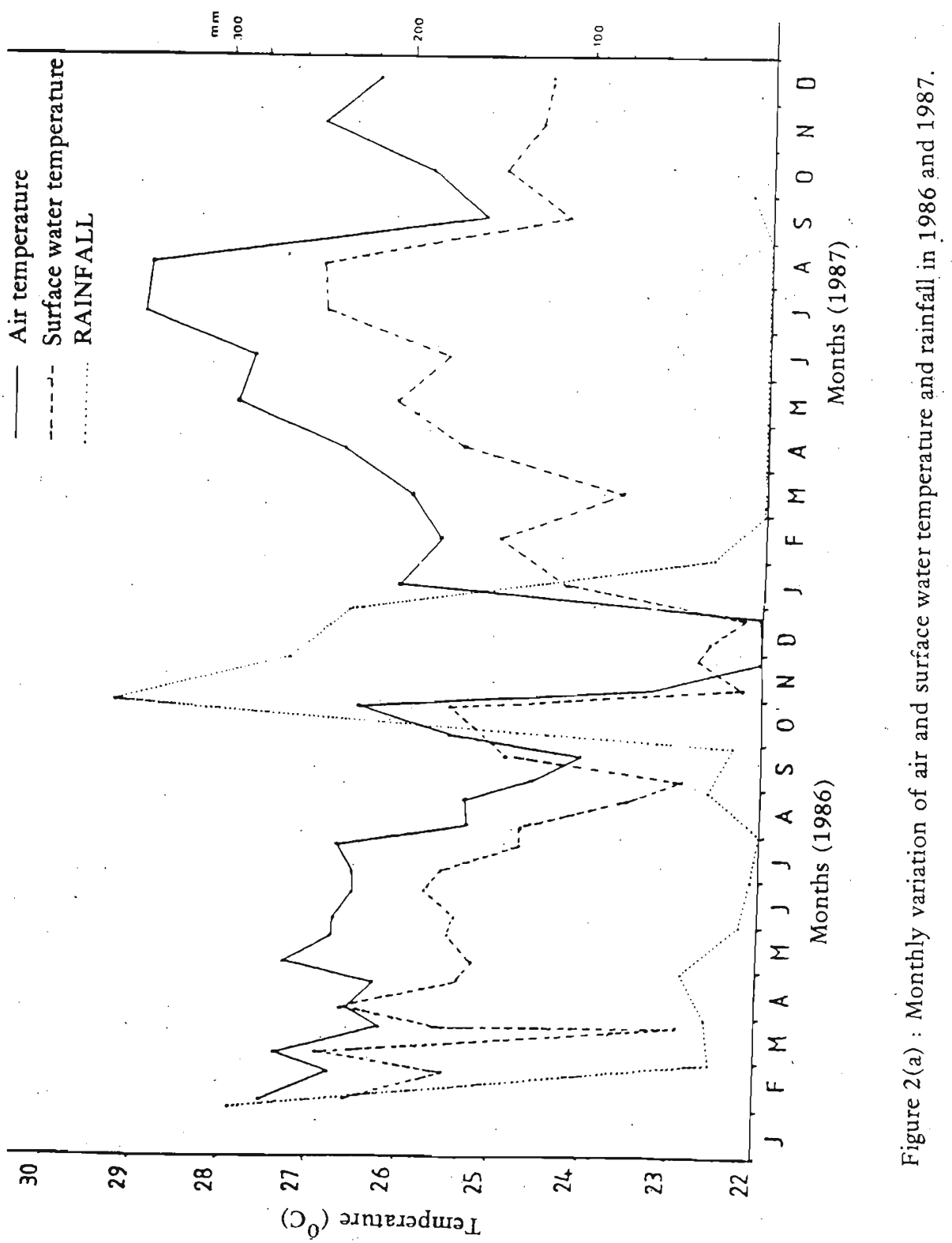




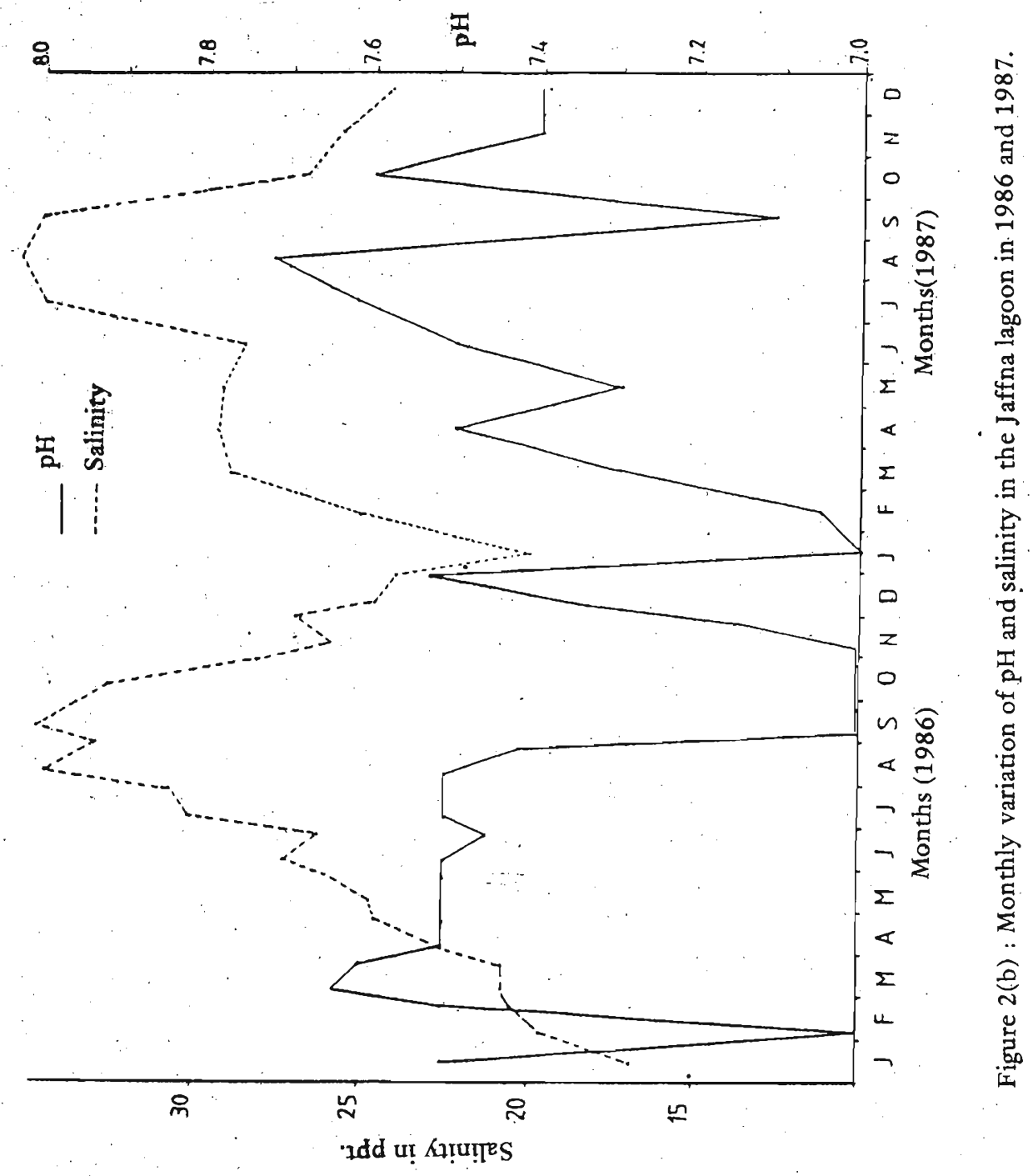


The lagoon water was either neutral or slightly alkaline during 1986 and 1987. In 1986 the lowest $\mathrm{pH}$ of 7.00 was in February, Sepetmber, October and November and the highest of 7.63 was in March. The lowest $\mathrm{pH}$ of 7.00 was in January and the highest. of 7.72 was in August 1987 (Figure 2b).

Figure 2a gives the rainfall data. The highest rainfall in 1986 was during January, October, November and December. In 1987, there was rain only during January and September. The rainfall data for October, November and December 1987 were not available.

Metapenaeus monoceros, Penaeus semisulcatus, Penaeus latisulcatus, Penaeus indicus and Penaeus monodon are the five species found in the Jaffna lagoon. M. monoceros and $P$. semisulcatus are the dominant species. The average percentage species composition for 1986 and 1987 are given below.

Table 3.

Average \% species composition

\begin{tabular}{lcc}
\multicolumn{1}{c}{ Species } & 1986 & 1987 \\
\hline Metapenaeus monoceros & 63.1 & 66.4 \\
Penaeus semisulcatus & 29.4 & 25.3 \\
Penaeus latisulcatus & 4.2 & 1.2 \\
Penaeus indicus & 2.2 & 5.9 \\
Penaeus monodon & 1.1 & 1.2 \\
\hline
\end{tabular}

According to the seasonal trends of prawn catches shown in Figure 3, February, July and December were productive months in 1986. During this period the GPUE varied from $5.01 \mathrm{Kg}$. gear $^{-1}$ day $^{-1}$ to $3.9 \mathrm{Kg}$. gear ${ }^{-1}$ day $^{-1}$ (Table 1). In 1987, February, March, April and May were productive months with the CPUE varying from $4.67 \mathrm{Kg}$. gear ${ }^{-1}$ day $^{-1}$ to $4.20 \mathrm{Kg}$. gear ${ }^{-1}$ day $^{-1}$ (Table 4). 


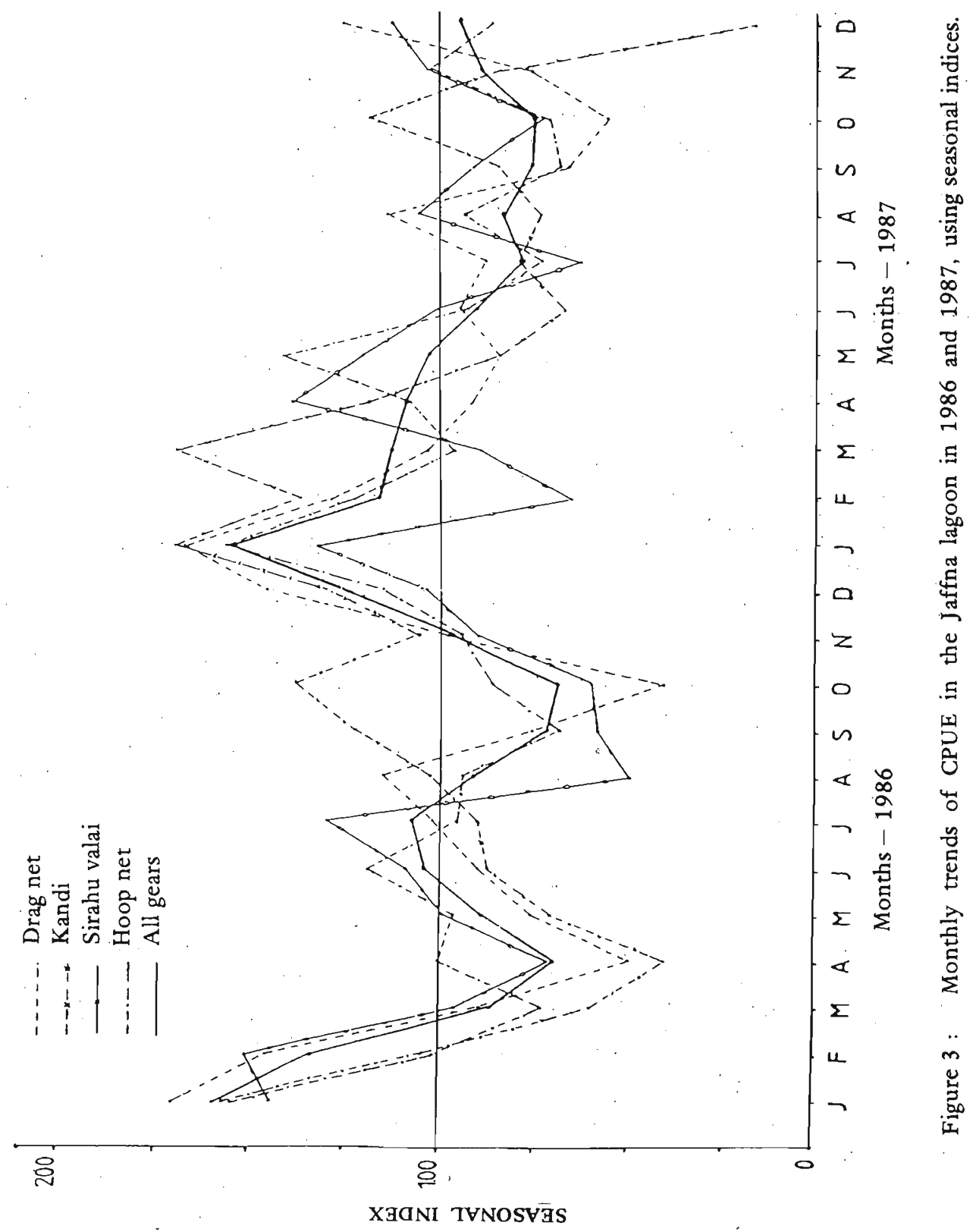




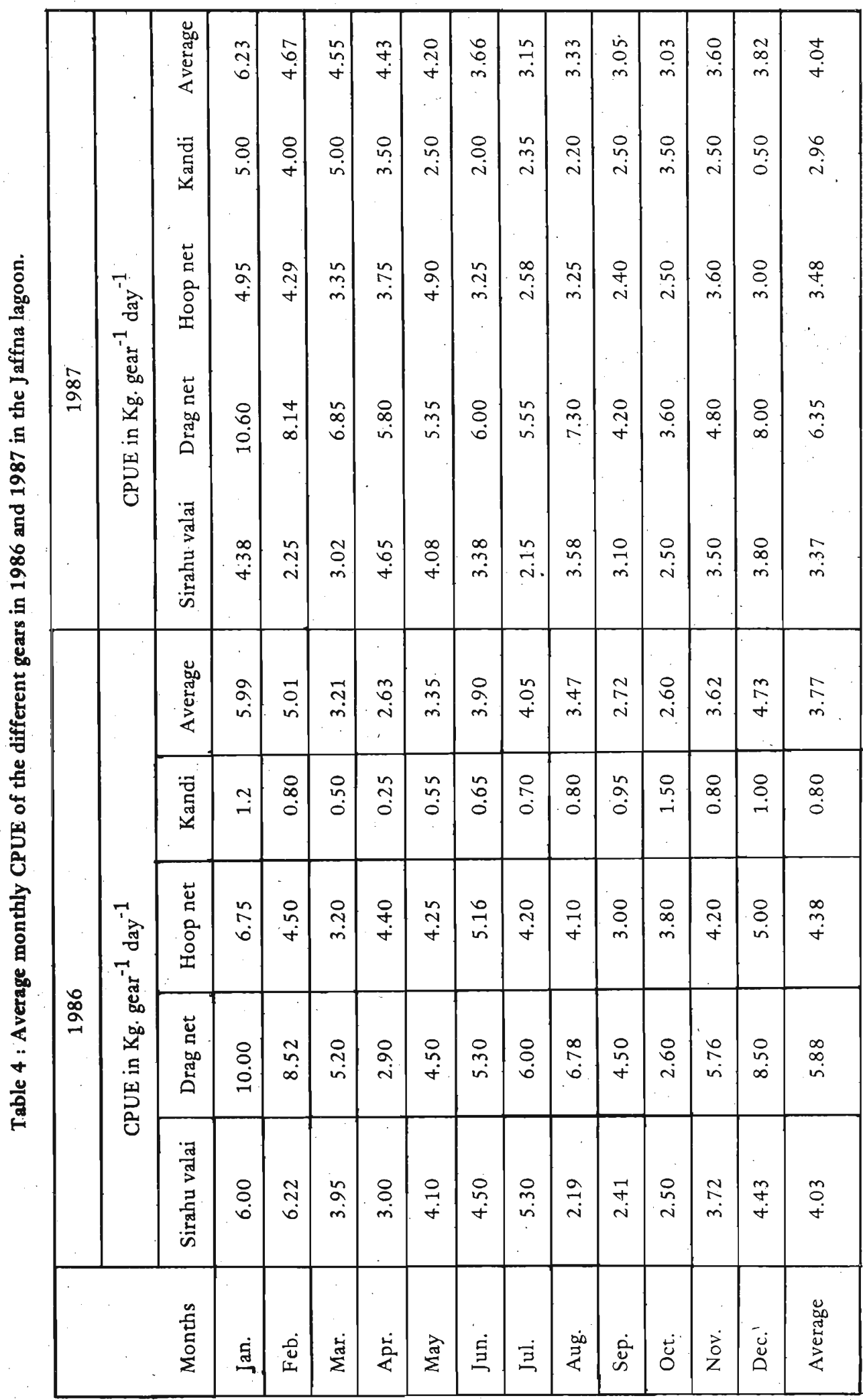


Taking the seasonal trends of prawn catches (Figure 3), generally 1987 was a more productive year with an annual average CPUE of $4.04 \mathrm{Kg}$ gear $^{-1}$ day $^{-1}$ irrespective of the gear used, compared with the annual average CPUE of $3.77 \mathrm{Kg}$. gear $^{-1}$ day $^{-1}$ in 1986 .

When the efficiency of the gears are compared (Table 1), it is evident that the drag net is the most efficient gear with an average CPUE of $5.88 \mathrm{Kg}$. gear $^{-1}$ day $^{-1}$ in 1986 and $6.35 \mathrm{Kg}$ gear $^{-1}$ day $^{-1}$ in 1987. Hoop net with an average CPUE of $4.38 \mathrm{Kg}$. gear ${ }^{-1}$ day $^{-1}$ in 1986 and $3.48 \mathrm{Kg}$. gear $^{-1}$ day $^{-1}$ in 1987 comes second, followed by sirahu valai with $4.03 \mathrm{Kg}$. gear ${ }^{-1}$ day $^{-1}$ in 1986 and $3.37 \mathrm{Kg}$. gear ${ }^{-1} \mathrm{day}^{-1}$ in 1987 . Kandi is the least efficient gear with only $0.80 \mathrm{Kg}$. gear $^{-1}$ day $^{-1}$ in 1986 and $2.96 \mathrm{Kg}$ gear $^{-1} \mathrm{day}^{-1}$ in 1987.

The average and range of total length of the penaeid prawns caught in the different gears in the Jaffna lagoon during 1986 and 1987 are shown in Table 5. The largest prawns were caught in sirahu valai and ranged in average total length from $6.69 \mathrm{~cm}$ to $11.96 \mathrm{~cm}$. The smallest prawns were caught in the drag net and ranged from $5.60 \mathrm{~cm}$ to $9.20 \mathrm{~cm}$ in total length. Metapenaeus monoceros and Penaeus semisulcatus are the dominant species in the drag net catches and their monthly average variations in total lengths are shown in Figure 4. The average total lengths of prawns caught by drag net during the months of February, May and October are respectively $5.00 \mathrm{~cm}, 4.94 \mathrm{~cm}$ and $5.70 \mathrm{~cm}$ for $M$. monoceros and $5.35 \mathrm{~cm}, 5.55 \mathrm{~cm}$ and $6.00 \mathrm{~cm}$ for $P$. semisulcatus in 1986 . In 1987 , the average total lengths are $4.85 \mathrm{~cm}$, $4.44 \mathrm{~cm}$ and $5.12 \mathrm{~cm}$ for $M$. monoceros during. March, May and October respectively and $6.35 \mathrm{~cm}, 5.36 \mathrm{~cm}$ and $6.10 \mathrm{~cm}$ for $P$. semisulcatus for the same period. 


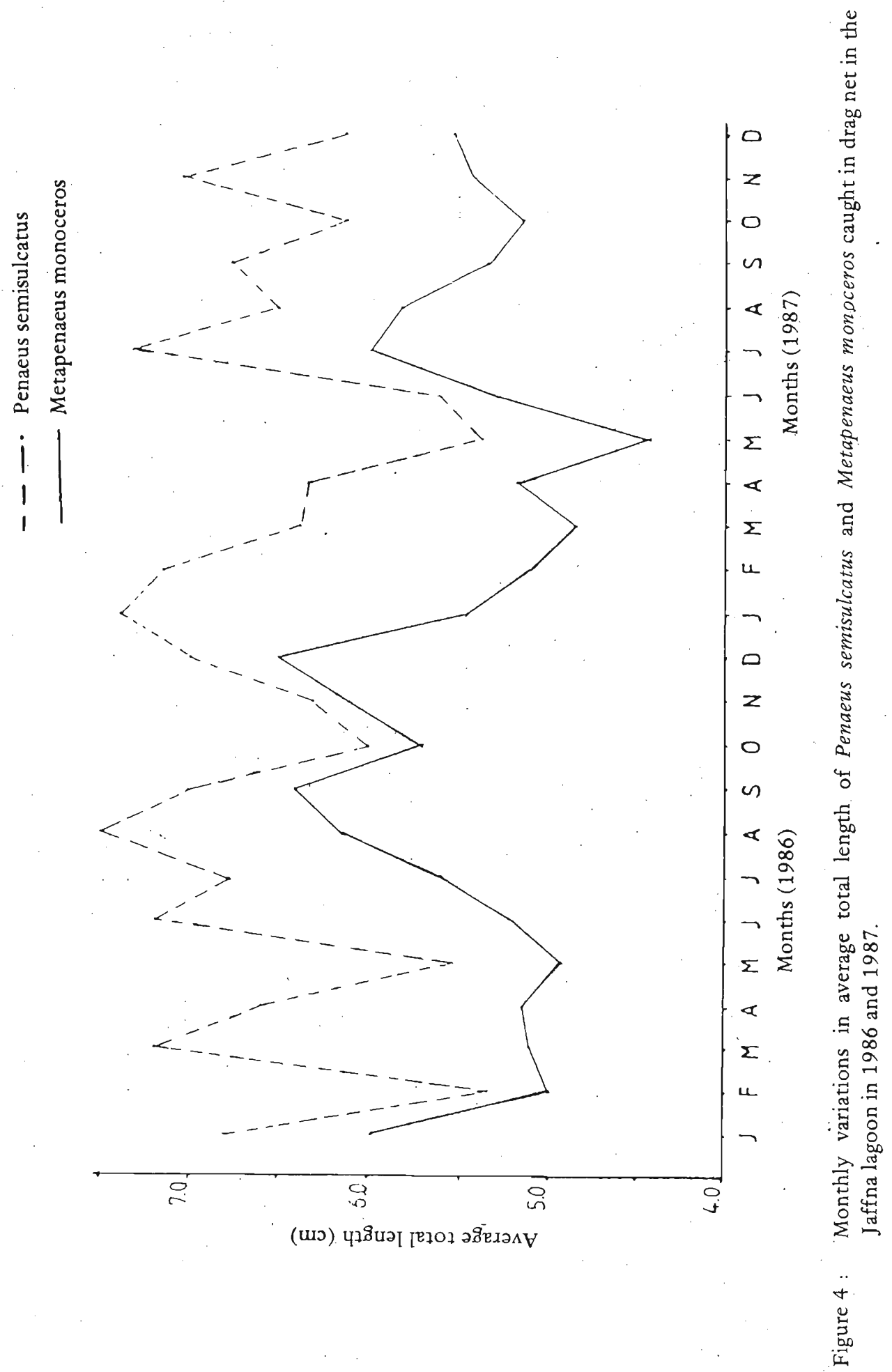


Efficiency of the Main Fishing Gears Used in Prawn Fishery

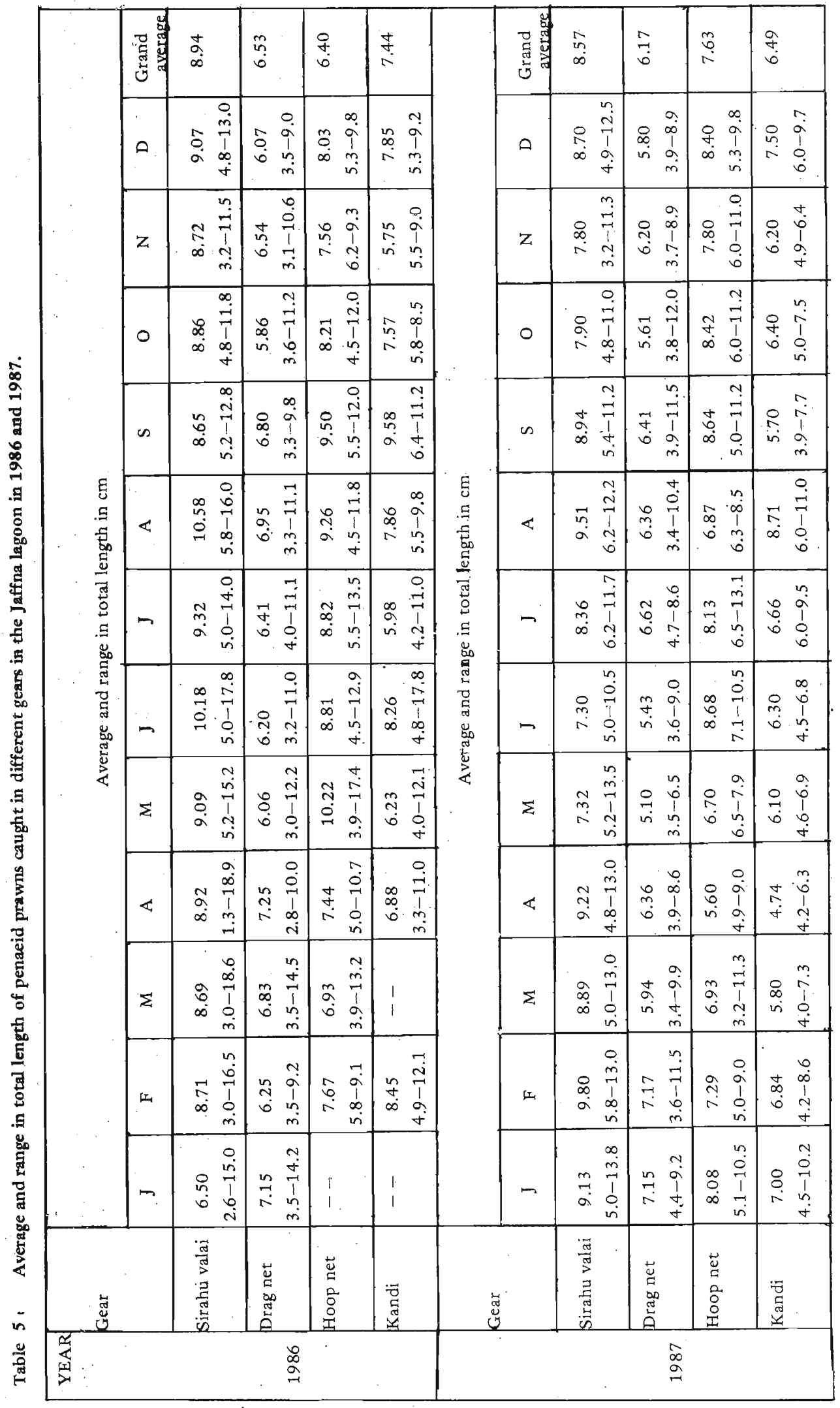




\section{Discussion}

The catch per unit of effort is used as an index of stock in the water body. ${ }^{5}$ The acquisition of a good estimate of fishing effort is one of the essential conditions to the assessment of the management. ${ }^{6}$ The stock and consequently the catch per unit of effort (CPUE) depend on a variety of environmental factors such as temperature, $\mathrm{pH}$, salinity, rainfall and the type of gear and its mesh size.

Sachithananthan ${ }^{12}$ had reported the salinity and temperature variations of surface waters of the Jaffna lagoon and the pattern of variation is similar to that during the present investigation.

In 1986 there was a high rainfall in January, October, November and December (Figure 2a). Salinity was low during these months, going down to $16.5 \mathrm{ppt}$. in January. The $\mathrm{pH}$ of the lagoon in 1986 was neutral during the months of February, September, October and November and was slightly alkaline during the rest of the period (Figure $2 \mathrm{~b}$ ). The average temperature of the surface water during January to March and December in 1986 and January 1987 were low ranging from $22.2^{\circ} \mathrm{C}$ to $26.0^{\circ} \mathrm{C}$. The corresponding air temperatures were $22.2^{\circ} \mathrm{C}$. and $27.1^{\circ} \mathrm{C}$ (Figure 2a). The CPUE in January was the highest for the year 1986, reaching an average of $5.99 \mathrm{Kg}$. gear $^{-1}$ day $^{-1}$ (Table 4).

In 1987 there was rain only during January and September (Figure 2a). The $\mathrm{pH}$ was neutral in January and alkaline during the rest of the year. The salinity reached the lowest of 20.05 ppt. in Januray (Figure 2b). The average monthly. CPUE was the highest in January with $6.23 \mathrm{Kg}$. gear ${ }^{-1}$ $\operatorname{day}^{-1}$ (Table 4).

Taking the average monthly CPUE for 1986 and 1987, on the whole, January, February and December could be considered as substantially productive months, as far as the prawn fishery in the Jaffna lagoon is concerned. Ranges of $16.8 \mathrm{ppt}$. to $25.35 \mathrm{ppt}$. in salinity 7.00 in $\mathrm{pH}$ and $22.35^{\circ} \mathrm{C}$ to $26.05^{\circ} \mathrm{C}$ in surface water temperature appear to favour production of prawns in the Jaffna lagoon.

The annual averge total lengths of $P$. semisulcatus and $M$. monoceros caught in 1986 are $6.58 \mathrm{~cm}$ and $5.65 \mathrm{~cm}$ respectively; the corresponding total lengths for 1987 are $6.48 \mathrm{~cm}$ and $5.29 \mathrm{~cm}$. Comparing the monthly average total length with the annual average total lengths of $P$. semisulcatus and M. monoceros for 1986 and 1987, it is apparent that in May and October the smallest size prawns are being harvested by drag net.

Table 5 shows the annual average total length of the penaeid prawns caught in the different gears during 1986 and 1987 in the Jaffna lagoon. The average size of prawns caught in 1986 in the different gears was larger than in 1987. 
The year 1987 was more productive than 1986. January seems to be most productive month in the Jaffna lagoon as far as the prawn fishery is concerned (Table 4).

Kandi is the cheapest of all the gears used in prawn fishery in the Jaffna lagoon. This is operated only at a few locations in the Jaffna lagoon and is being abandoned due to its poor efficiency $\left(0.8 \mathrm{Kg}\right.$. gear ${ }^{-1} \mathrm{day}^{-1}$ and. $2.96 \mathrm{Kg}$. gear $^{-1}$ day $\left.^{-1}\right)$. Sirahu valai is the most expensive gear used in the lagoon, collects the largest prawns and is more efficient $\left(4.03 \mathrm{Kg}\right.$. gear ${ }^{-1}$. day $^{-1}$ ) than hoop net and drag net. A hoop net unit costs half that of sirahu valai, two times that of drag net and four times that of kandi and is slightly more efficient $\left(4.38 \mathrm{Kg}\right.$. gear ${ }^{-1}$ day $^{-1}$ and $3.48 \mathrm{Kg}^{-}$gear $^{-1} \mathrm{day}^{-1}$ ) than sirahu valai.

Hoop net is becoming increasingly popular due to its mobility, easy installation, fair cost and efficiency. The drag net with an average CPUE of $5.88 \mathrm{Kg}$. gear $^{-1} \mathrm{day}^{-1}$ and $6.35 \mathrm{Kg}$. gear ${ }^{-1}$ day $^{-1}$ is the most productive gear. It costs half that of hoop net and.collects the smallest specimens of all the species, especially during the months of May and October. Unregulated operation of drag net poses danger for the future viability of the prawn fishery in the Jaffna lagoon and to the socio-economic benefits presently existing in this area.

Taking into account the average total lengths of prawns and CPUE during 1986 and 1987 , it is evident that the retention of the small size prawns of May and October for at least a month in the lagoon will substantially increase prawn production in the lagoon. Total ban or at least a restriction of the use of drag net during the months of May and October in the Jaffna lagoon is therefore recommended. This measure will in addition bring an end to the frequent disputes between those operating the drag net and those operating the other gears (especially sirahu valai) in the Jaffna lagoon, based on the allegation that the drag net collects the smallest prawns and deprives them of a potential profitable catch.

It is necessary to continuously study the changes in the structure of the penaeid prawn population as influenced by the fishery and the lagoon environment. Depending on the results further management measures can be proposed. It seems that in most of the lagoons there are prospects for both increased employment and greater fishery out put if rational management is practised. $^{2}$

\section{Acknowledgement}

The financial assistance provided by the Natural Resources, Energy and Science Authority of Sri Lanka on Research grant No. RG/86/B/01 is acknowledged with thanks. Particular thanks are due to the Technical Assistants Mr. G. Illangovan and Mr. S.A. Gladstone for their helpful assistance in the field and laboratory. 


\section{References}

1. ADCP REPORT (1980) Strategy for development of aquaculture in Sri Lanks. Report of a Planning Mission. Sep. - Oct 1980. ADCP/MR/81/15.

2. BEN - TUVIA, A. (1984) Some aspects of the management of Bardawill Lagoon. In management of Coastal lagoon Fisheries. Edited by James M. Kapetsky. No. 61, 2, pp. 530-539.

3. CHITRAVADIVELU, K. \& ARUDPRAGASM, K.D. (1983) Studies on the prawn fishery in " the Jaffna lagoon. Proc. Sri Lanka Assoc. Advmt. Sci. 39(1) : 47 (abstract).

4. CHITRAVADIVELU, K. (1987) Some aspects of gears used in prawn fishery in the Jaffna lagoon. Proc. Sri Lanka Assoc. Advmt. Sci. 43(1) : 45 (abstract).

5. CUSHING, D.H. (1981) Fisheries Biology - A study in population dynamics. The University of Wisconsin Press. pp : 233.

6. GARCIA, S. \& RESTE, L. Le (1981) Life cycles, dynamics, exploitation and management of coastal Penaeid shrimp stocks. FAO Fisheries Technical Paper No. 203.

7. KURIAN, C.V. \& SEBASTIAN, V.O. (1976) Prawns and prawn fishery of India. Hindustan Publishing Corporation. Printing Press, Delhi 110007 (India). pp. 245.

8. LAEVASTU, T. (1965) Manual of methods in Fisheries Biology: Section 5. Field observations on Fishing operations. FAO Manuals Fisheries Science No. 1.

9. PEARSON, J. (1923) Fishing appliances of Ceylon. Bulletin No. 3, pp. 65-132.

10. PEDNI, M. (1981) Penaeid shrimp culture in tropical developing countries. FAO Fish. Circ. 732 : pp. 14.

11. ROSSI, R. et al. (1984) Management of aquaculture and fishing in the Scardovari Fishery (Po River Delta, Italy). In management of Coastal Lagoon Fisheries. Edited by James M. Kapetsky: No. 61, 2, pp. 441-458:

12. SACHITHANANTHAN, K. (1969) Salinity and temperature variations of the surface waters in the Jaffna lagoon. Bull. Fish. Res. Stn. Cey. 20, pp. 87-99.

13. SACHITHANANTHAN, K. \& PERERA, W.K.T. (1970) Topography and substratum of the Jaffna lagoon. Bull. Fish. Res. Stn. Cey. 21(2) pp. 75-85.

14. SACHITHANANTHAN, K. \& THEVATHASAN, A. (1970) Sirahu valai - A passive fishing gear in Ceylon. Bull. Fish. Res. Stn., Ceylon. 121(2) pp. 75-85.

15. SCB/GEN/81/30, (1981) Report of the workshop on the Biology and resources of Penaeid shrimps in South China Sea Area. 30th June - 5th July, 1980. South China Sea Fisheries Development and Co-ordinating Programme. pp. 143. 